\title{
The Transoceanic 1755 Lisbon Tsunami in Martinique
}

\author{
J. Roger,${ }^{1,2}$ M. A. Baptista, ${ }^{1}$ A. Sahal,${ }^{3}$ F. Accary,${ }^{2,3}$ S. Allgeyer, ${ }^{4}$ and H. Hébert ${ }^{4}$
}

\begin{abstract}
On 1 November 1755, a major earthquake of estimated $M_{\mathrm{w}}=8.5 / 9.0$ destroyed Lisbon (Portugal) and was felt in the whole of western Europe. It generated a huge transoceanic tsunami that ravaged the coasts of Morocco, Portugal and Spain. Local extreme run-up heights were reported in some places such as Cape St Vincent (Portugal). Great waves were reported in the Madeira Islands, the Azores and as far as the Antilles (Caribbean Islands). An accurate search for historical data allowed us to find new (unpublished) information concerning the tsunami arrival and its consequences in several islands of the Lesser Antilles Arc. In some places, especially Martinique and the Guadeloupe islands, $3 \mathrm{~m}$ wave heights, inundation of low lands, and destruction of buildings and boats were reported (in some specific locations probably more enclined to wave amplification). In this study, we present the results of tsunami modeling for the 1755 event on the French island of Martinique, located in the Lesser Antilles Arc. High resolution bathymetric grids were prepared, including topographic data for the first tens of meters from the coastline, in order to model inundations on several sites of Martinique Island. In order to reproduce as well as possible the wave coastal propagation and amplification, the final grid was prepared taking into account the main coastal features and harbour structures. Model results are checked against historical data in terms of wave arrival, polarity, amplitude and period and they correlate well for Martinique. This study is a contribution to the evaluation of the tele-tsunami impact in the Caribbean Islands due to a source located offshore of Iberia and shows that an 8.5 magnitude earthquake located in the northeastern Atlantic is able to generate a tsunami that could impact the Caribbean Islands. This fact must be taken into account in hazard and risk studies for this area.
\end{abstract}

Key words: Tsunami, earthquake, Caribbean, far-field, wave amplification, run-up.

1 Centro de Geofisica da Universidade de Lisboa, Rua Ernesto de Vasconcelos, Faculdade de Cièncias, Ed. C8, 6 1700 Lisbon, Portugal. E-mail: jeanrog@ hotmail.fr

2 Ecole Normale Supérieure, Laboratoire de Géologie, UMR 8538, 24, rue Lhomond, 75231 Paris Cedex 5, France.

3 Université Paris 1 Panthéon-Sorbonne, Laboratoire de Géographie Physique, UMR 8591, 1 place Aristide Briand, 92195 Meudon Cedex, France.

4 CEA, DAM, DIF, 91297 Arpajon, France.

\section{Introduction}

Martinique Island is part of a subduction volcanic arc of $850 \mathrm{~km}$ length, resulting from the convergence of the Atlantic Plate under the Caribbean Plate at an average rate of $2 \mathrm{~cm} /$ year (STEIN et al., 1982) (Fig. 1). This subduction is the cause of shallow earthquakes, some of them with magnitude greater than 7, as was the case of the 5 April 1690, 8 February 1843 (Feuillet et al., 2002) the 18 November 1867 Virgin Island $M_{\mathrm{w}}=7.5$ earthquake (ZАніво et al., 2003a, b) and the 21 November $2004 M_{\mathrm{w}}=6.3$ earthquake of Les Saintes (Zаніво et al., 2005). Important seismic activity is also associated with magmatic activity. The volcanic activity itself can generate pyroclastic flows or lahars that are able to reach the sea and create tsunamis (De LANGe et al., 2001; Waythomas and WatTs, 2003).

Tsunamis observed in the area result from strong magnitude earthquakes $(M \geq 7)$, namely the 1867 Virgin Islands $M_{\mathrm{w}}=7.5$ earthquake (O'LoughLIN and LANDER, 2003; ZAHibo et al., 2003a, b), or from submarine mass failures (for example, see LopezVenegas et al., 2008) as the 14 January 1907 Jamaica landslide (O'Loughlin and LANDER, 2003), or the potential landslide on the flank of the Kick'em Jenny underwater volcano (SMith and SHEPHERD, 1996). Such a landslide could be very large in the Lesser Antilles (Deplus et al., 2001; Le Friant et al., 2009).

According to Pelinovsky et al. (2004), volcanic eruptions in the area may also cause tsunamis, as was the case of the July 2003 eruption in Montserrat. For Martinique Island, tsunami waves were observed at least in April 1767 following an earthquake SE of Barbados, and in 1902 due to the volcanic eruption and explosion of Mount Pelée (O’Loughlin and LANDER, 2003). LANDER et al. (2002) collected data from around 30 tsunamis for the Caribbean region 

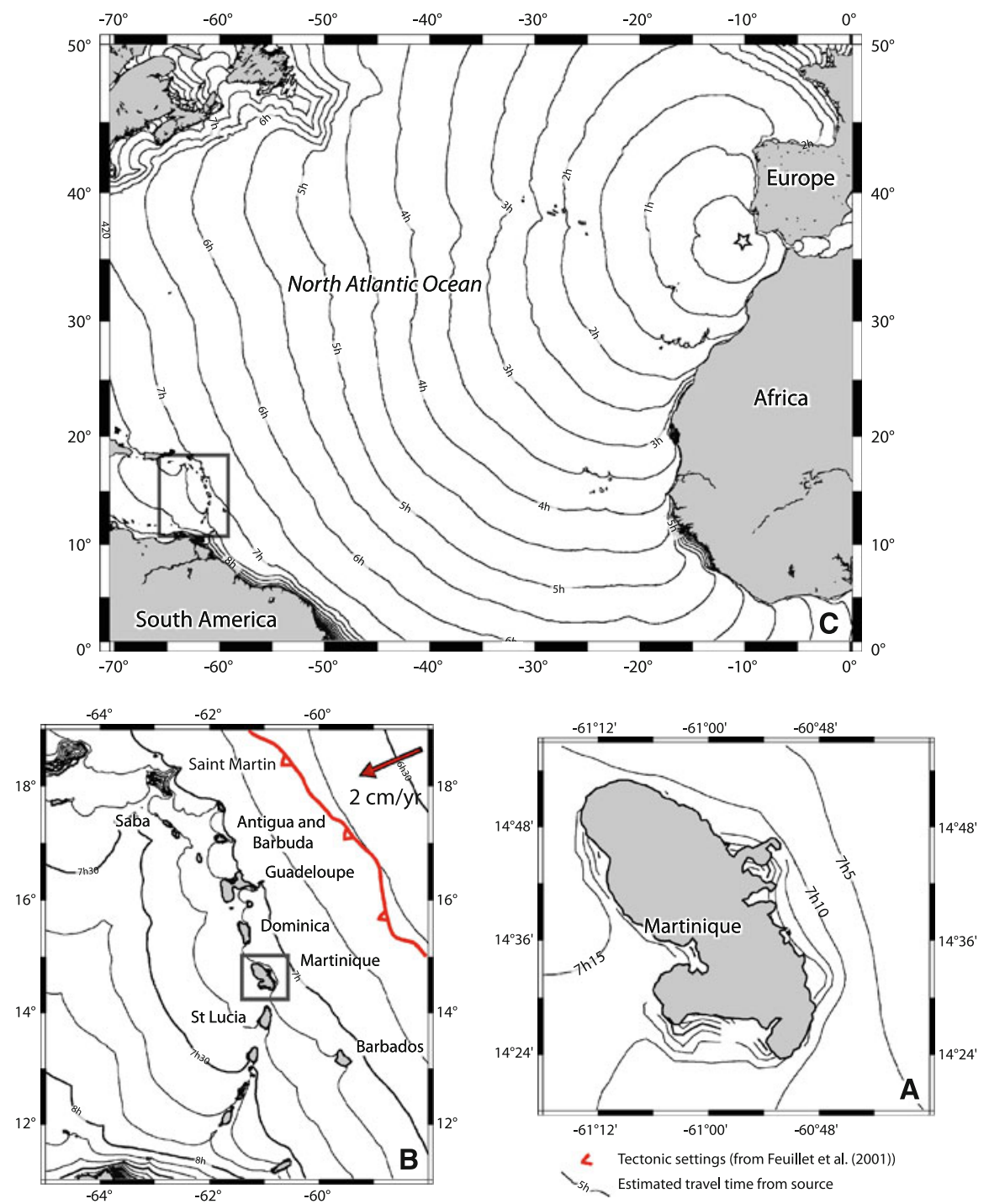

Figure 1

Geographic map locating Martinique Island (a) within the Lesser Antilles Arc (b) and in the North Atlantic Ocean (c). The tsunami travel times (TTT), based on a point source (white star) close to the source of Baptista et al. (2003), are represented by continuous black curves

including local sources (source distance $<200 \mathrm{~km}$ ), regional events $(<1,000 \mathrm{~km})$ and transoceanic events $(>1,000 \mathrm{~km})$. Among them, reliable sources report observations for the 1755 Lisbon tsunami.

The tsunami observed in the Antilles at that time has been associated with the great Lisbon earthquake of November 1, 1755. This event was observed all along the eastern Atlantic shores from Morocco to the United Kingdom, and caused many casualties and damage (BAPTISTA et al., 1998b, 2009a). In addition, numerous coeval reports indicate important abnormal waves in the Antilles.

Recent results of tsunami modeling show that an earthquake with magnitude up to 8.0/8.5 with an epicenter located offshore the Iberian Peninsula is indeed able to produce significant wave heights in the western Atlantic (BARKAN et al., 2009), and more particularly in the coastal areas of Guadeloupe Island (Roger et al., 2010), $7 \mathrm{~h} 30 \mathrm{~min}$ of tsunami propagation after the main shock (see tsunami travel times on Fig. 1). 
In order to shed some light on the event observed in the French Antilles on 1 November 1755, we made a detailed search for historical documents on these islands and we present here a compilation of those observations with focus on Martinique Island.

The main objective of this study is to test the impact of a tsunami generated by a seismic source proposed for the 1755 event using numerical modeling and high resolution bathymetric data near the coast. We investigate the tsunami far field propagation and the coastal wave amplification close to Martinique Island. The results of numerical modeling correlate well with the available historical data in some selected sites in Martinique Island.

\section{The 1755 Event}

On 1 November 1755, a great earthquake of estimated magnitude $M=8.5 \pm 0.3$ (SOLARES and Arroyo, 2004) destroyed the town of Lisbon and was felt in the whole of western Europe, as far east as Hamburg (Germany). Compilations of historical data concerning the earthquake are presented by SousA (1919), Machado (1966), Solares and Arroyo (2004), while compilations on tsunami data are presented in RoMero (1992), BAPTISTA et al., (1998a, 2003), KAABOUBEn et al. (2009) and BARKAn et al. (2009).

Several authors investigated the source of the Lisbon earthquake, using either macroseismic data (Machado, 1966; Martínez Solares et al., 1979; LEVRET, 1991; SolARES et al., 2004), average tsunami amplitudes (ABE, 1979), or scale comparisons with the 28 February 1969 event (Johnston, 1996). A different approach was considered by BAPTISTA (1998) and BAPTISTA et al. (1998a, b) throughout the systematic study of the historical records of the 1755 tsunami wave heights observed along the Iberian and Morocco coasts. These authors proposed a source location, based on tsunami hydrodynamics modeling, located close to the southwest Portuguese continental margin. Zitellini et al. (1999) identified a very large active, compressive, tectonic structure located $100 \mathrm{~km}$ offshore SW Cape St Vincent (Marques de Pombal thrust fault) which was proposed as a good candidate for the generation of the 1755 event, although its dimensions cannot justify the seismic moment of the 1755 earthquake. Later, BAPTISTA et al. (2003) used this structure to build a composite source and checked its reliability against the NE Atlantic tsunami data.

An alternative solution was proposed by GUTSCHER et al. (2002) as an active accretionary wedge overlying an eastward dipping basement and connected to a steep, east dipping slab of cold, oceanic lithosphere beneath Gibraltar. Tsunami simulation results, using this source geometry, are presented in GUTSCHER et al. (2006). Vilanova et al. (2003) considered an event triggered in the Lower Tagus Valley as the source of most of the damage observed close to Lisbon, and even of some "tsunami like" phenomena described in Oeiras and along the estuary of the Tagus River (BAPTISTA and MirandA, 2009b). Recently, a new source based on historical data in the NW Atlantic and far-field tsunami modeling was proposed with an orientation perpendicular to previously suggested trending features (BARKAN et al., 2009).

\subsection{Historical Data}

\subsubsection{Data Sources and Descriptions}

The results of the research of historical data concerning the observation of the 1755 tsunami in the Caribbean are summarized in Table 1, showing that the tsunami was observed on several islands, including the French Antilles.

Most of these reports have been quoted in later documents such as the Procès-Verbal des Séances de l'Académie des Sciences of 1756 (Anonymous, 1755; LetTée, 1755), or the supplement to the Gentleman's Magazine (URBAN, 1755). Most of the reports provide information on the location of historical observations (Table 1). Indeed, at this time, Martinique Island was among the most important trade center, especially Fort-de-France's Bay, attended by experienced sailors.

The accurate reading of these documents allows us to conclude that there are only three distinct sources of information: the first one is the letter read by Duhamel concerning an anonymous witness (Anonymous, 1755); the second one is the letter of LetTÉE (1755); and the third one is the document 


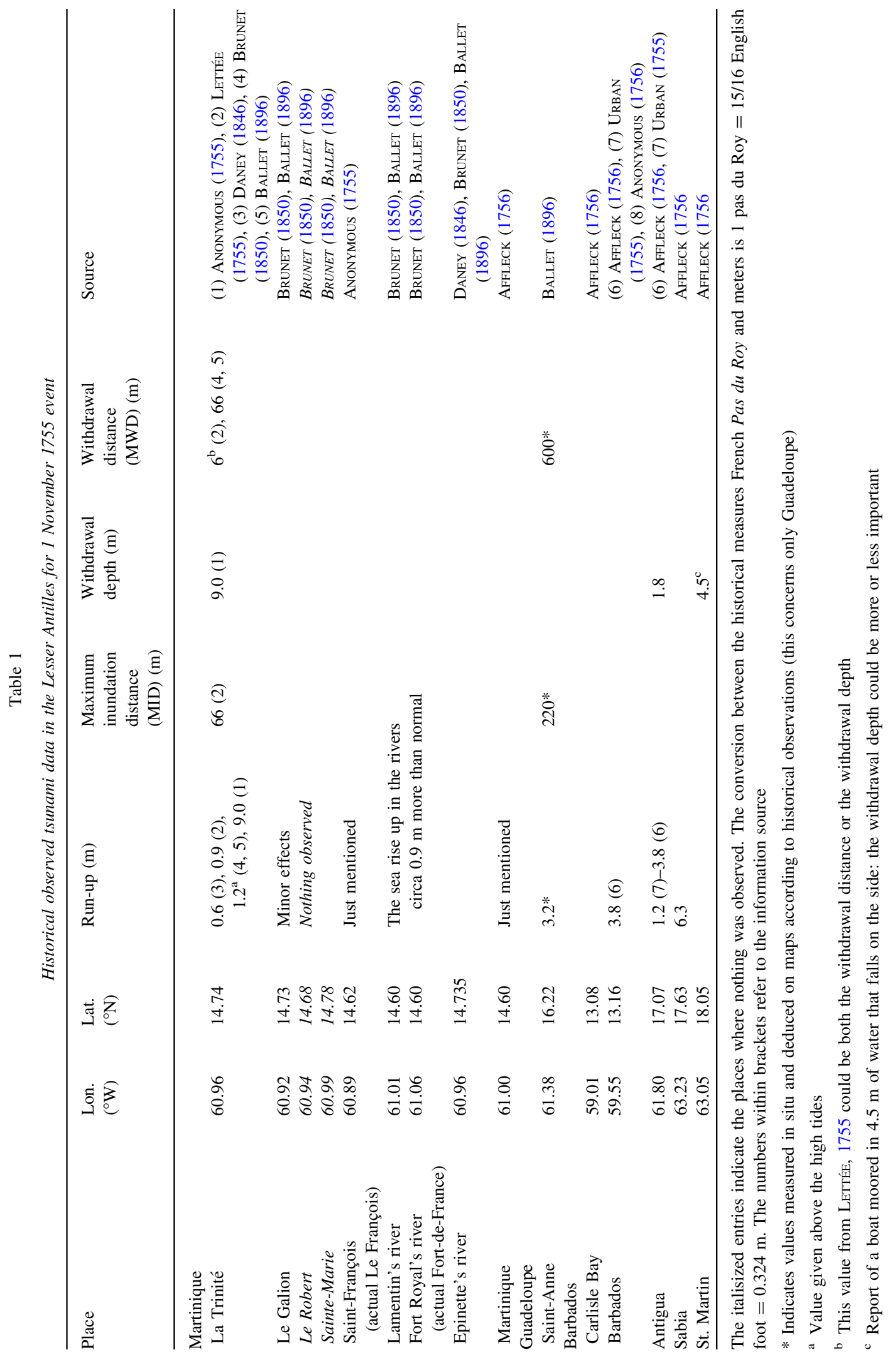




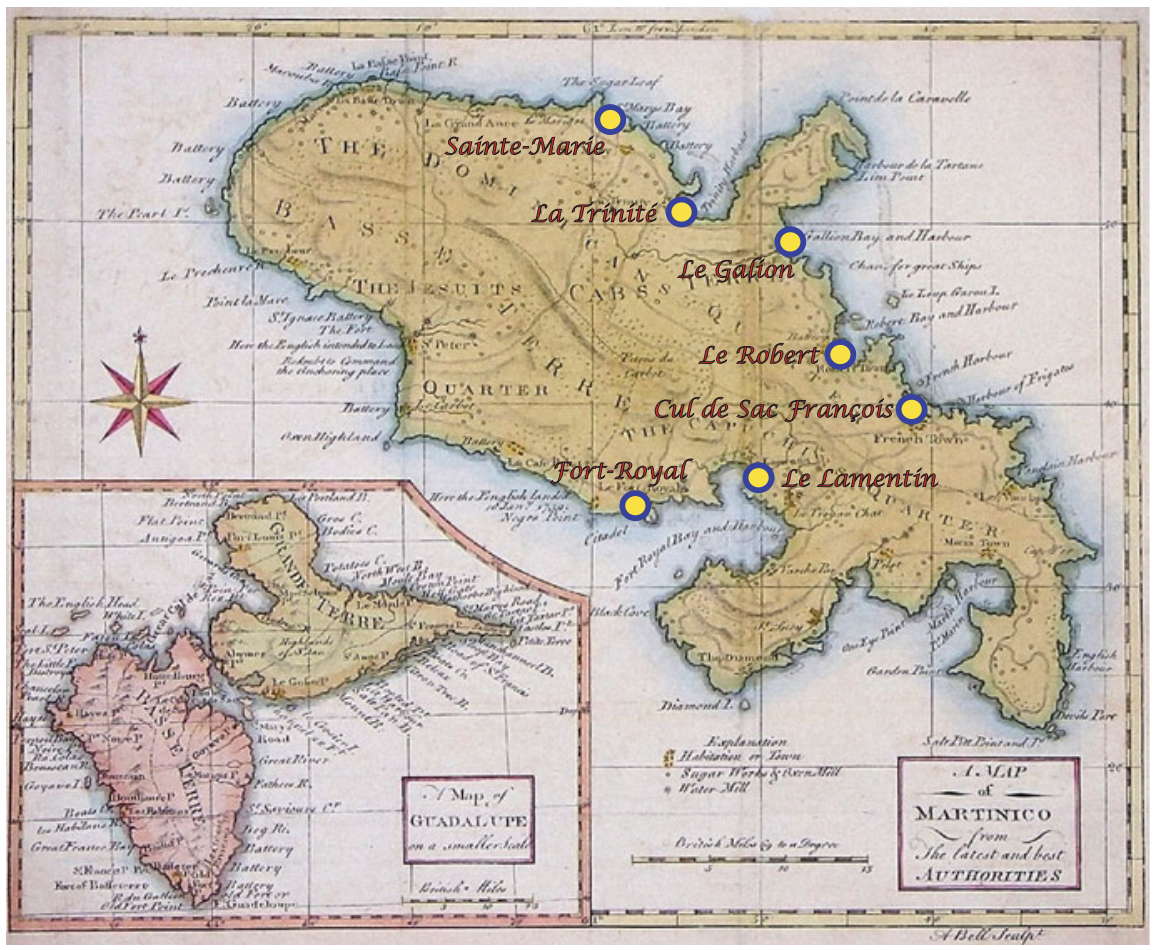

Figure 2

Geographical location of the historical observations and studied sites on Martinique Island on an historical map of Martinique and Guadeloupe Islands (BELL, 1759, Courtesy of J. Bodington.)

certainly used by DANEY (1846), BRUNET (1850) and BALLET (1896).

However, this third document is by far the richest one with respect to the tsunami. It is a very precise description of the hydrological phenomenon, focusing especially on La Trinité Bay, describing the various oscillations of the sea level: the succession of flows and withdrawals, amplitudes, periods, etc. In most records, the arrival of several waves is mentioned (actually flow and withdrawal), the first one not always being the strongest. The same document also informs us about the observation or the nonobservation of these same wave-trains around the island: limited at Le Galion Bay, nothing at either Le Robert or in St Marie, an "unusual deposit" by the sea in the Epinette River, and specific responses of the Lamentin and the Fort-Royal Rivers (west coast) are also mentioned. These locations are indicated on a British marine map of this period (Fig. 2).

The letter read by Duhamel (Anonymous, 1755) indicates that the sea reached about $9 \mathrm{~m}(30 \mathrm{ft}$, in the original) above its usual level four times. The phenomenon was observed from La Trinité Bay to the François Cul-de-sac. LetTÉE (1755) indicates that the phenomenon started at 4 p.m. at La Trinité Bay, beginning with a 6-meter drop of the sea level $(20 \mathrm{ft}$, in the original), flooding the shore $60 \mathrm{~m}$ inland (200 ft, in the original), damaging houses up to $1 \mathrm{~m}$ from the ground. It took $30 \mathrm{~min}$ for the sea level to return to normal.

Concerning the other islands of the Antilles (Barbados, Guadeloupe, Saba and St Martin, located on Fig. 1), we can find some information about the inundation of docks in harbors, streets, houses and other.

We tried to read/interpret all this information in terms of tsunami parameters. All details concerning the number of waves, the period, and the height are summarized in Table 1.

\subsection{Studied Sites in Martinique}

The studied sites are presented in Fig. 2. These are La Trinite Bay, located on the east coast of the 
Table 2

Parameters of the two source segments used for tsunami modeling

\begin{tabular}{lllllllllllll}
\hline Source & & $\begin{array}{l}\text { Lon. } \\
\left({ }^{\circ}\right)\end{array}$ & $\begin{array}{l}\text { Lat. } \\
\left(^{\circ}\right)\end{array}$ & $\begin{array}{l}\text { Depth of } \\
\text { center of fault } \\
\text { plane }(\mathrm{km})\end{array}$ & $\begin{array}{l}\text { Average } \\
\text { slip }(\mathrm{m})\end{array}$ & $\begin{array}{l}\text { Strike } \\
\left(^{\circ}\right)\end{array}$ & $\begin{array}{l}\text { Dip } \\
\left({ }^{\circ}\right)\end{array}$ & $\begin{array}{l}\text { Rake/slip } \\
\text { angle }\left(^{\circ}\right)\end{array}$ & $\begin{array}{l}\text { Length } \\
(\mathrm{km})\end{array}$ & $\begin{array}{l}\text { Width } \\
(\mathrm{km})\end{array}$ & $\begin{array}{l}\text { Rigidity } \\
(\mathrm{N} \mathrm{m})^{2}\end{array}$ & $\begin{array}{l}\text { Mo } \\
(\mathrm{N} \mathrm{m})\end{array}$ \\
\hline $\begin{array}{l}\text { BAPTISTA } \text { et al. } \\
(2003)\end{array}$ & GB & -8.7 & 36.1 & 20.5 & 20 & 250 & 45 & 90 & 105 & 55 & $30.010^{9}$ & $3.4610^{21}$ \\
\hline
\end{tabular}

island, and Fort-de-France Bay, on the west coast of the island, presenting a special focus on the harbor (already here in 1755) and the international airport of Le Lamentin.

A few other sites, mentioned in the historical reports, are also analyzed: Ste-Marie, Le Galion Bay, Le Robert, St-François. These sites are presented in Fig. 2.

\section{Tsunami Modeling}

\subsection{The Model Earthquake}

The model earthquake used in this study for the 1755 earthquake is the double segment source proposed by BAPTISTA et al. (2003), that includes the Marques de Pombal thrust fault (MPTF) identified by ZitelLini et al. (1999), and a second thrust fault oriented along the Guadalquivir Bank (GB).

They are included in Fig. 1 (as a point source) and their parameters, presented in Table 2, account for a $M_{\mathrm{w}} 8.5$ earthquake with a seismic moment of $M_{\mathrm{o}}=6.63 \times 10^{21} \mathrm{~N} \mathrm{~m}$.

The selection of this model earthquake was based upon two facts: (1) GuTSCHER et al. (2002)'s proposed source produces late tsunami arrivals in the near field (GUTSCHER et al., 2006); (2) BARKAN et al. (2009)'s source is not a tectonic based source and its direction cuts the most prominent structures in the area, although it is able to radiate energy towards the Caribbean.

\subsection{Numerical Method}

The numerical model used in this study is based on the non linear shallow water wave theory. It allows us to compute tsunami generation and propagation associated with an earthquake and has been used for years in order to study tsunami hazards for various exposed regions, from French Polynesia (Sladen et al., 2007) to the Mediterranean Sea (Alasset et al., 2006; Roger and HéBert, 2008; Yelles-Chaouche et al., 2009; Sahal et al., 2009).

Our method assumes instantaneous displacement of the sea surface, identical to the vertical sea-bottom deformation, transmitted without losses to the entire water column; the vertical sea-bottom deformation is computed using the elastic dislocation model of ОкаDА (1985). Given the initial free surface elevation, the model solves the hydrodynamical equations of continuity (1) and momentum (2). Non linear terms are taken into account, and the resolution is carried out using a finite difference method centred in time and using an upwind scheme in space.

The inundation is calculated based on the methodology presented by KowaLIK and MurTy (1993), relying on an extrapolation of the fluxes calculated in wet cells and in dry meshes:

$$
\begin{gathered}
\frac{\partial(\eta+h)}{\partial t}+\nabla[v(\eta+h)]=0 \\
\frac{\partial v}{\partial t}+(v \nabla) v=-g \nabla \eta
\end{gathered}
$$

$\eta$ corresponds to the water elevation, $h$ to the water depth, $v$ to the horizontal velocity vector, $g$ to the gravity acceleration.

\subsection{Bathymetric Grids}

The wave propagation is calculated from the epicenter area offshore of the Iberian Peninsula (southern Portugal and Spain to the east) across the Atlantic Ocean on six levels of imbricated grids of increasing resolution, approaching the Lesser Antilles including Martinique Island with special focus on $\mathrm{La}$ Trinite Bay and Fort-de-France Bay. The largest grid (grid 0, level 1), corresponding to the geographical 
coordinates of Fig. 1a, is built from GEBCO World Bathymetric Grid 1' (IOC, IHO and BODC, 2003) and is just a resampling of this grid at a space step of $5^{\prime}(\sim 9,250 \mathrm{~m})$. The grid resolution increases close to the studied site in order to account for a correct description of shorter wavelengths. Indeed, the wave celerity is expressed by $c=\sqrt{g h}$ (in shallow water non dispersive assumption), and thus decreases when $\mathrm{h}$ decreases near the coast, implying wave shortening. The time step used to solve the equations decreases when the grid step decreases, and respects for each grid level the Courant-Friedrichs-Lewy (CFL) criterion to ensure the numerical stability. The resolution for the levels 2 (grid 1), 3 (grid 2), 4 (grid 3), 5 (grid 4) and 6 (grid 5 and 6) are, respectively, $1^{\prime}(1,850 \mathrm{~m}$ ), $500,150,40$ and $20 \mathrm{~m}$. The highest resolution grids (levels 5 and 6), 40 and $20 \mathrm{~m}$, correspond to the zooms on La Trinité Bay and the northern part of Fort-de-France Bay including the harbor and
Lamentin International Airport. The bathymetric dataset was obtained through the merging of GEBCO $1^{\prime}$ data, high resolution multi-beam and resampled bathymetric data from the French Hydrographic Service (SHOM). The intermediate grids (1-4) have been included for numerical stability reasons and correct wavelength sampling during the imbrication. In order to compute tsunami propagation on land, topographic data were manually digitized from topographic maps published by IGN (2006a, b, c).

\section{Modeling Results and Comparison with Historical Data}

Figure 3 displays the maximum water heights computed across the Atlantic Ocean after 9 h 30 min of propagation. It shows three main energy paths: the strongest towards South America (Brazil), a second

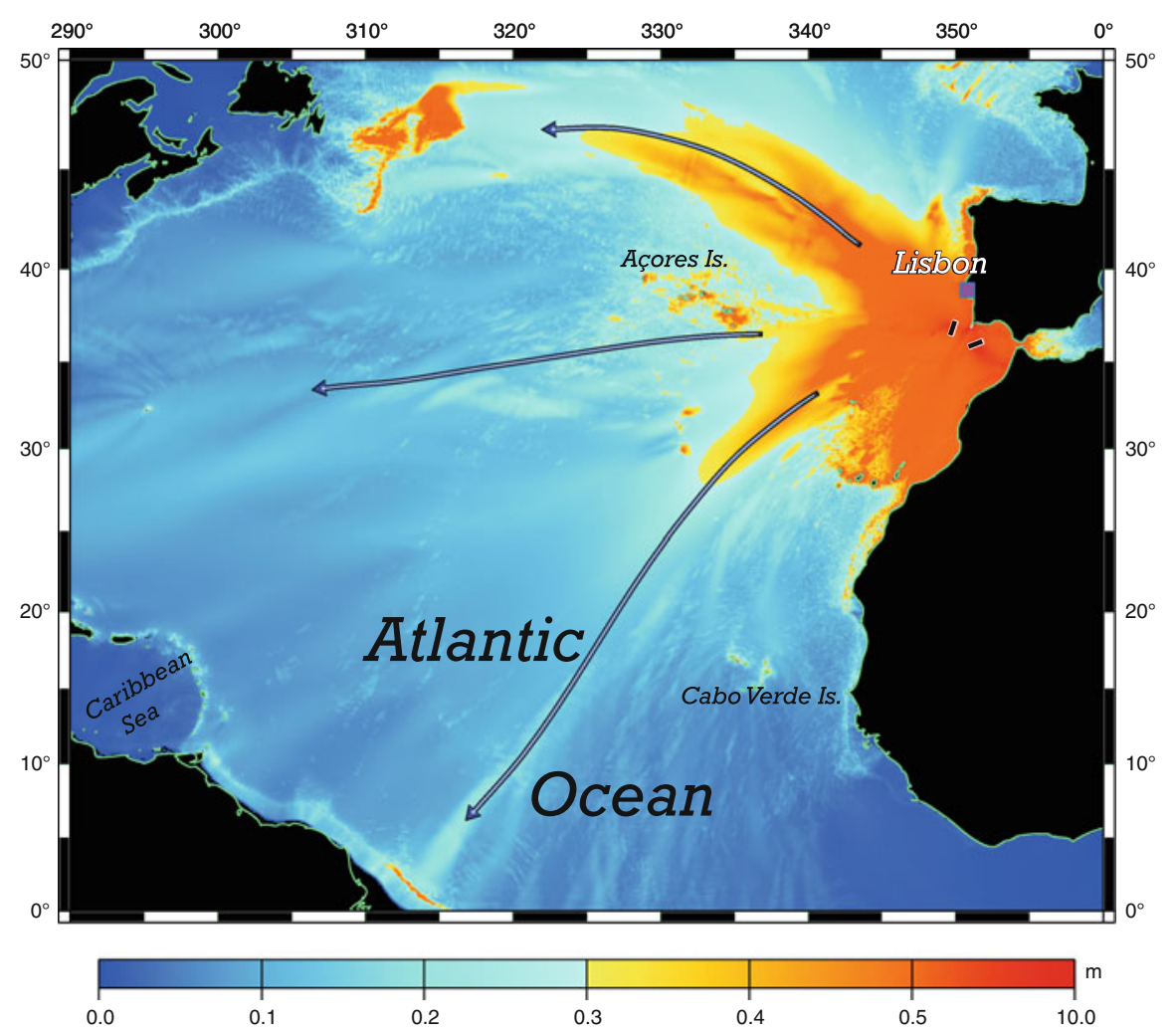

Figure 3

Maximum wave heights over the Atlantic Ocean after 9 h 30 min of tsunami propagation, calculated with the combined source of Baptista et al. (2003). The arrows highlight the three main tsunami energy paths. The two segments of the source are represented by the black and white rectangles 
towards Newfoundland and the weakest towards the USA (Florida). This radiation pattern is due to the geometrical shape of the source and its azimuth, and to the most relevant submarine features (submarine basins, ridges and transform faults, for example) along the oceanic path that will act as waveguides during tsunami propagation as noted by SATAKE (1988), HéBeRT et al. (2001) and Titov et al. (2005). It is worth noting that the Caribbean area is not among the most impacted areas for this computed tele-tsunami on this large-scale grid.

In Fig. 4, we present the maximum wave heights along Martinique Island (grid 2, resolution $500 \mathrm{~m}$ and grid 3, resolution $150 \mathrm{~m}$ ) obtained after 9 h $30 \mathrm{~min}$ of tsunami propagation. It clearly shows that only a few sites are prone to wave amplification around the island. This corresponds to sites either directly exposed to long wave arrival coming from the Iberian Peninsula or also located on the other side of the island, in the Caribbean Sea. The wave heights observed along the coast of Martinique vary between 1 and $2 \mathrm{~m}$. The coastal segment from the bay of La Trinite and the north coast of the neighboring Presqu'tle de la Caravelle to the north of the island near Le Lorrain exhibits maximum values of more than $2 \mathrm{~m}$. Along the southeast coast, the bays of Le Galion, Le Robert and Le François, the wave heights are generally less significant. Then the southeastern coast of the island, offshore of Le Vauclun, shows again significant wave heights of more than $1.5 \mathrm{~m}$.

The potential protective role of the fragmented coral reef barrier from Le Vauclun to Le Galion (shown in Fig. 4) against long wave arrivals has to be stressed. The display of the maximum tsunami height with a shaded bathymetric gradient shows a relative protection of the coastal sites by the coral reef, on the southeastern part of the island. This residual coral reef (appearing as a line on the right) leads to an attenuation of the tsunami effect for the thusprotected bays of Le Galion, Le Robert and Le François. The northeastern (La Trinité, Ste Marie, Le Lorrain) and southern part of the island, which are probably not protected enough by the coral reef which is too deep (5-10 m under sea level), shows again some significant wave heights, at the northern part of the island, from La Trinité to Le Lorrain and farther north.
The surfing spots indicated in Fig. 4 highlight the coastal areas not protected by a sufficient coral reef barrier against classic wind long waves.

Figure 5 (grid 5 and 6) present a focus on the specific site of La Trinité Bay and Fort-de-France Bay and neighboring areas after $9 \mathrm{~h} 30 \mathrm{~min}$ of tsunami propagation. It shows the maximum water height reached by the sea level and the flow depth (maximum wave height minus topography) on land.

The high resolution (20 and $40 \mathrm{~m}$ ) grids of $\mathrm{La}$ Trinité and Fort-de-France Bays (Fig. 5) are able to reproduce the segments of this coral reef barrier, the harbour morphology and coastal shapes as well as the shallow bathymetric features that could affect significantly tsunami propagation near the coast and might contribute to wave trapping and amplifications, potentially associated with resonance phenomena (Roger et al., 2010).

We can clearly see that several places are inundated in both grids, sometimes until several hundreds of meters from the shore: until $100 \mathrm{~m}$ in La Trinité and $250 \mathrm{~m}$ in La Moïse, on the east side of La Trinité Bay; and until more than $1 \mathrm{~km}$ in Fort-de France Bay (near the airport). This inundation is especially significant all around La Trinite Bay where we can find flow depth values of more than $2 \mathrm{~m}$ in the town but also in other urban areas such as La Clique and Anse Cosmy (north of La Trinité) and La Moïse, on the eastern side of the bay (Fig. 5). The $9 \mathrm{~m} \mathrm{(30} \mathrm{ft)} \mathrm{wave}$ height value indicated in Anonymous (1755) (Table 1) is probably a mistake; it is likely between 3 and $30 \mathrm{ft}$ if we refer to the other descriptions at $\mathrm{La}$ Trinité (Lettée, 1755; Daney, 1846; Brunet, 1850; BALLET, 1896). The presented results show a maximum inundation distance (MID) of about $100 \mathrm{~m}$ in the southern part of the bay (the town of La Trinité), and $250 \mathrm{~m}$ in the northeastern area (Anse Cosmy); thus, longer than the historical observations. However, this computed inundation limit may be overestimated due to the fact that friction is not considered and this may be important in urban areas.

Concerning Fort-de-France Bay (grid 6), the wave heights are smaller than in La Trinite (by about a factor of 3), but they can reach $1.5 \mathrm{~m}$ offshore of Fort St-Louis and in the inlet of Château Lézards, deep inside of the bay, south of the airport of Le Lamentin. In addition, several places exhibit inundation, in the 


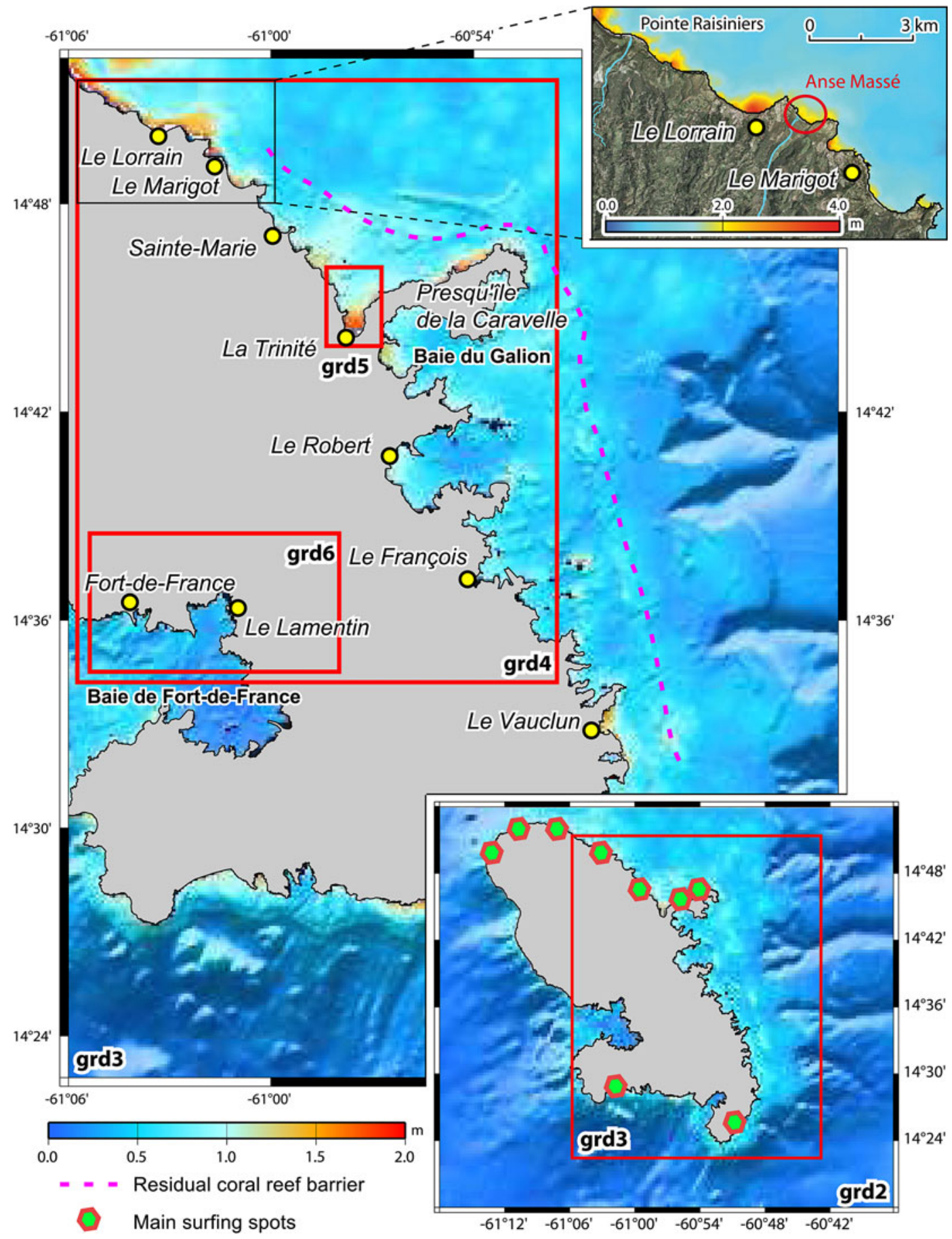

Figure 4

Maximum wave heights illuminated by a bathymetric gradient on Martinique Island on grid 2 and 3 after 9 h 30 min of tsunami propagation using Baptista et al. (2003)'s seismic source. The yellow dots are the places mentioned in the text. The red rectangles show the location of the different imbricated grids. A focus (black rectangle on grid 3) shows evidence of wave amplification offshore of a lagoon domain (Anse Massé) southwestward to Le Lorrain. The residual coral reef barrier is indicated with dashed pink curve (from Battistini, 1978). The main surfing spots are indicated by green hexagons (from http://www.wannasurf.com) 

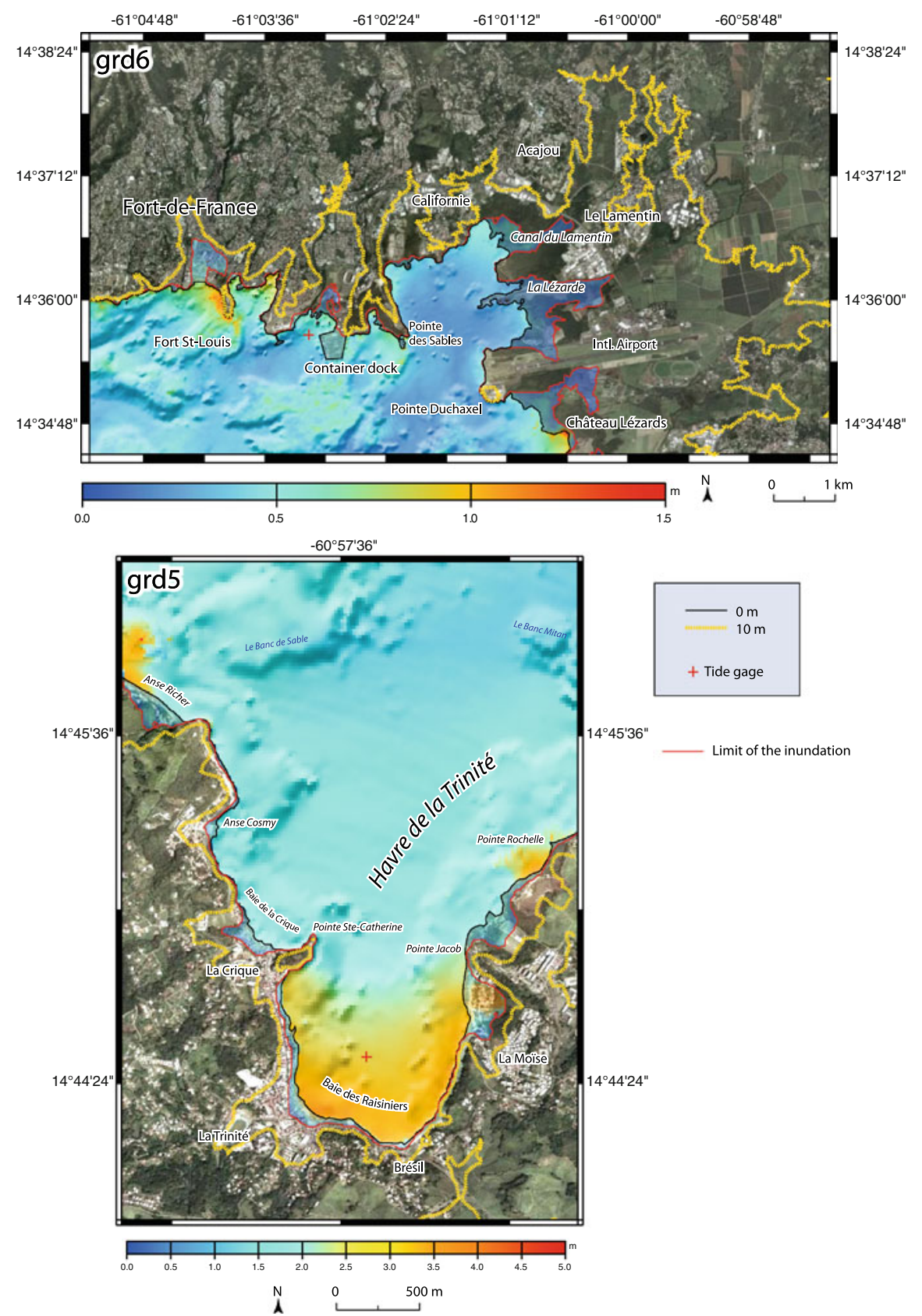

Figure 5

Maximum wave heights illuminated by a bathymetric gradient at sea and maximum water depth on land in high resolution grids 5 and 6 after $9 \mathrm{~h} 30 \mathrm{~min}$ of tsunami propagation. The red line underlines the inundation limit. The red crosses represent the synthetic tide gauges location.

The altitude limits of 0 and $10 \mathrm{~m}$ are indicated, respectively, by black and yellow lines

Fort-de-France town center, which is very low and in the area of the container dock, but also the areas close to the canal of Le Lamentin and the Lézarde River, close to the airport, which are partially inundated. All these inundations in Fort-de-France Bay happen in low lands and mostly in swamps with maximum wave heights of no more than $50 \mathrm{~cm}$. This is in good agreement with the historical data indicating that the Lamentin River, located north of the Airport, was subject to an abnormal phenomenon on 1 November 


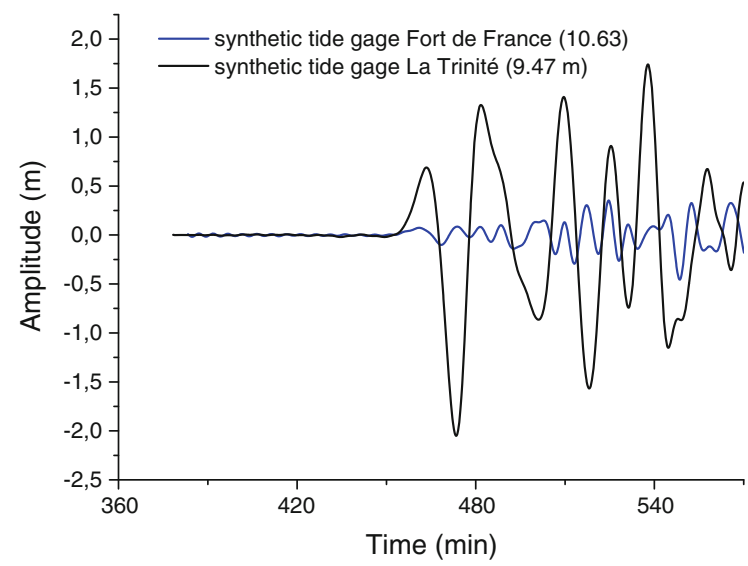

Figure 6

Synthetic maregrams obtained after $9 \mathrm{~h} 30 \mathrm{~min}$ of tsunami propagation for two synthetic tide gauges located in the bays of La Trinité and Fort-de-France. Their positions are given in Fig. 4. The water depth at the gauge location is indicated

1755 with the sea rising up in the rivers 3 feet $(\sim 90 \mathrm{~cm})$ more than normal (BALLET, 1896).

Synthetic tide gauges have been positioned (Fig. 5) in order to obtain information concerning principally tsunami arrival, wave polarities, amplitude and periods at specific locations in both bays.

Figure 6 represents the synthetic signal recorded by two synthetic tide gauges located on both sides of the island, one in La Trinite Bay and one in Fort-deFrance Bay. It shows that the effects of the tsunami would be less dramatic in Fort-de-France Bay than they would be in La Trinite Bay at approximately the same water depth $(\sim 10 \mathrm{~m})$. Then it indicates that the first tsunami wave arrives in La Trinité Bay within a travel time of about $7 \mathrm{~h} 30 \mathrm{~min}$. This is in agreement with the time announced in the available historical documents.

Concerning La Trinité, the computed polarity and the relative amplitudes are in agreement with the reported historical facts: there is a small sea elevation of $70 \mathrm{~cm}$ (reported to be $60 \mathrm{~cm}$ above the maximum tide level) followed by an significant withdrawal in about $10 \mathrm{~min}$ (reported to occur in $4 \mathrm{~min}$ ) and then a significant inundation of the docks and the streets. The time between the first two waves has been estimated to be $15 \mathrm{~min}$. The computed time between these two waves is around $20 \mathrm{~min}$. According to BALLET (1896)'s accurate description of the phenomenon in
La Trinité, we are globally in good agreement concerning periods and relative amplitude between each wave, except for the position of the most significant and destructive wave: it is reported to be the fourth one (BALLET, 1896) but the results of computation show that it is the fifth (Fig. 6).

\section{Discussion}

The effects of the tide and friction have not been considered in this study.

The historical tide prediction (done using the actual mean sea level with data from 1980-1985 for Le Robert and data from 2005-2008 for Fort-deFrance) on 1 November 1755 for Le Robert indicate that, despite the fact that the amplitude of tide was only of about $40 \mathrm{~cm}$ crest to trough, the sea was up or at the beginning of withdrawal at 2 p.m., the hour of arrival of the tsunami according to the historical documents. For data concerning Fort-de-France, the amplitude of tide has been estimated to be less than $20 \mathrm{~cm}$ crest to trough. In both cases, this tide amplitude certainly could have had an additional effect on the tsunami coastal amplification and inundation, even a negligible effect regarding the tsunami height of more than $3 \mathrm{~m}$ in La Trinité Bay.

The simulations have been done without taking into account the friction effects. Even though DotsENKO (1998) shows that the dissipation due to friction effects is negligible offshore (open-sea and shelf areas), DAO and TKALICH (2007) show that the roughness parameter is important in wave-shore interaction including shallow water and inundation friction. This is something important to be noted because it means that, in our case, the friction term is equal to 0 and, thus, the run-up limits presented in the following are certainly overestimated regarding the computed scenarios. In fact, if the friction is important due to the presence of lots of buildings or dense vegetation, for example, so the propagation on land will be slowed down more quickly than without buildings (Yanagasiwa et al., 2009). According to HÉBERT et al. (2009) the non consideration of friction could correspond to an overestimation of wave heights of about $30 \%$. 


\subsection{Role of Coastal Features}

It is important to try to reproduce as well as possible the coastal and bathymetric features in low water depth, i.e. in the area of wave shoaling and refraction processes around seafloor topographic highs, because the particular characteristics of the coastline (coastal geo-morphology, e.g. the geometry of bays, harbours, slope of beaches), or the presence of submarine canyons or coral reef barriers, will have direct consequences on the wave behavior and amplification factor and on the inundation or run-up (Chatenoux and Peduzzi, 2005, 2007; Cochard et al., 2008; Duong et al., 2008).

In the same way, as underlined by ROGER and HÉBERT (2008) for the Balearic Islands in the Mediterranean Sea, the knowledge of the location of submarine canyons is important to assess the tsunami hazard along the coasts because of the focusing role they can play on long wavelengths. Thus, the impact on long waves of the submarine canyons located a few kilometers from the shore in the southeastern part of the island (Fig. 3) should be determined in the future, especially if the coral reef, actually acting as a shield, is going to disappear.

Thus, La Trinité is a U-shaped bay (or funnelshaped bay), with a maximum length of about $1.2 \mathrm{~km}$ and a maximum width of about $1.0 \mathrm{~km}$, oriented N-S and opened northward with a mean depth of $4 \mathrm{~m}$ and a very low bathymetric slope $\left(0.33^{\circ}\right)$. This shape is particularly interesting to consider in the case of tsunami wave amplification studies and hazard assessment. In fact, this apparently protected bay with a narrow inlet can amplify the tsunami, and thus its destructive power, presenting a funnel-shape for the arrival waves to travel through (MONSERRAT et al., 2006). This could explain the observed and modeled wave amplification at this specific location. In addition, it is important to mention that the coral reef barrier in front of this bay could be qualified as residual, i.e. not able to protect the bay against long wave arrival because it is too deep and cut. This situation is emphasized by the high touristic frequentation all year long, especially for this location.

Fort-de-France is located eastward of swamplands, lowlands bordering the Lamentin River, and is constantly inundated with a mean altitude of less than
$1 \mathrm{~m}$ above sea level. In spite of the fact that the historical reports do not mention any catastrophic wave arrival in Fort-de-France Bay in these places in 1755 , the present vulnerability of the area should be taken into account because of its economical central role, located in lowland areas. This omega-shaped $(\Omega)$ bay (9 km length and $3 \mathrm{~km}$ width in the narrowest place) is oriented E-W and opened westward. Its maximum water depth is about $30 \mathrm{~m}$ in the boats channel to the harbor but elsewhere it is only about $10 \mathrm{~m}$ deep at most. The general bathymetric slope of the bay from the east (Lamentin Airport) to the west (entrance of the bay) is less than $0.1^{\circ}$.

Several authors have referred to the effects of the presence of coral reef barriers close to the coast, such as the increase in the propagation time, and the reduction of the amplitude (BABA et al., 2009). But on the other side, CochARD et al. (2008) indicate that when fragmented, waves are able to accelerate through so-created channels.

For Martinique Island, Fig. 4 shows that the coral reef barrier could be qualified as residual; only a line of $25 \mathrm{~km}$ length between the presqu'lle de la Caravelle and Le Vauclin is visible. The progressive disappearance of the coral reef in Martinique is due to geological reasons such as fast subsidence or volcanic eruptions (BAtTistini, 1978), and to human stresses such as the pollution or the overfishing in these rich areas (Bouchon et al., 2008; LEGRAND et al., 2008).

This happens in particular offshore of the northeast coast where the reef does not protect from the assault of normal waves because it is generally underwater at 5-10 $\mathrm{m}$ depth (BAtTistini, 1978) as shown in Fig. 4 with the location of surfing spots. In fact, only the southeastern part of the reef remains, partially protecting the coast from classical waves, with a width sprawl of about 1-2 km; three of the sites discussed in this paper are affected: the bays of Le Galion, Le Robert and Le François. In 1755, according to the historical documents, we know that nothing was observed in Le Robert and just a little in Le Galion (BALLET, 1896). Despite the fact that we have not tested the real effect of this coral barrier, the general results obtained with maximum wave heights in the case of the 1755 event are in favor of this. 
Le François is only mentioned in one document (ANONYMOUS, 1755), but in view of this supposed important protection by the different coral reef parts at this time, we could easily suppose that it was too protected to receive anything or that there was simply nobody able to report something there, or was at mean significant damage/impact in 1755. Thus, numerical modeling results of maximum wave heights of about $0.5-1.0 \mathrm{~m}$ inside this bay (Fig. 4) could mean that the used bathymetry on the coral reef has changed in 250 years in agreement with the previous remark concerning the coral disappearance.

On the contrary, Sainte-Marie, located north of La Trinité, shows a good exposure to long wave arrival and thus the tsunami modeling (Fig. 3) indicates significant wave heights (more than $1.5 \mathrm{~m}$ ) in this location in spite of the fact that historical reports clearly mention that nothing was observed here on 1 November 1755 (BALLET, 1896).

The lack of historical information concerning wave arrival near the urban coastal areas of Sainte-Marie, Le Marigot or Le Lorrain in the north and Le Vauclain in the south, where numerical modeling indicates wave heights of more than $2 \mathrm{~m}$ (Fig. 4), could be explained by the lack of population here in 1755, according to the available historical maps of 1753 (Le Rouge, 1753) and 1759 (BELL, 1759), or simply the lack of educated people able to write a report of the phenomenon. A search for tsunami deposits in some typical lagoon areas on La Martinique Coast as behind the Anse Massé with the Lorrain River or the Capot River at the Pointe des Raisiniers (Fig. 4) could provide additional information about this tsunami of 1755 .

\subsection{Discussion on Vulnerability and Hazard Map Purposes}

The results shown in Fig. 5 could be considered as a contribution to the tsunami (hazard) vulnerability map of La Martinique Island. The use of satellite views reveals the location of populated areas and economic interests in general, correlated with a water elevation map (sea and land) on these high resolution grids (Fig. 5).

The maximum wave heights are well correlated with the surfing spots as in the case of Guadeloupe
Island (Roger et al., 2010), i.e. the places of high touristic frequentation (Fig. 4).

At the time of the 1755 tsunami, the population of the French Antilles is not known exactly, but in Martinique, it corresponds to about 100,000 inhabitants, including 84,000 slaves. The shore inhabitants were mainly fishermen and sailors. Although it was populated, the vast majority of the population lived quite far from the shore working in sugar cane activity. Historical synthesis reports that most of them were illiterates (about 95\% of the whole population of the French Antilles).

Nowadays, the situation is quite different; the French Antilles count 810,000 inhabitants, including about 400,000 inhabitants for Martinique, with an important influx of tourists estimated to reach about 1 million people per year, resulting in highly frequented beaches, especially during high season. Also, the main economic activities are located along the shore with an estimated income of about 278 million euros in 2007 (Comité Martiniquais du Tourisme, 2008): the development of the tourism industry and the lack of a coastal management policy has furthermore increased this exposure, leading to a concentration of $90 \%$ of the population along the shores, in places less than $20 \mathrm{~m}$ high (SCHLEUPNER, 2007), which is to say 343,000 inhabitants in 1999 (INSEE, 1999). This population is highly exposed to coastal inundation hazards.

In addition, our study also clearly shows that some vital exchange areas (economic, touristic, and above all, for emergency aid) such as Lamentin International Airport or the container's dock (Fort-deFrance harbor) are prone to tsunami inundation due to the wave arrival from the eastern Atlantic Margin, despite its orientation towards the west (especially the low lands of no more than one meter altitude (and particularly the airport runway).

\section{Final Conclusion and Perspectives}

This study shows that the historical observations of 1 November 1755 tsunami in Martinique Island can be reproduced using a tsunami source located offshore of Iberia. The predicted inundation parameters are in 
agreement with the historical reports at La Trinité and Fort-de-France Bay.

It also indicates that some places along the coast seem to be partially protected from tsunami impact by the residual coral reef barrier. This point deserves further in situ investigations.

Martinique is presently a highly populated island offering some of the most popular tourist beaches in the Caribbean. There could be considerable human casualties in the case of a tsunami event. In fact, this part of the world is well-prepared for hurricane hazards, but is relatively unprepared for the suddenness of a tsunami-like event, especially coming from the eastern part of the Atlantic Ocean.

The tsunami risk in Martinique is not quite existent in people's minds, as meteorological events (storms, cyclones) occur more frequently. Local administrations are not much prepared for tsunamis and rescue units vulnerable to earthquakes and inundations from the sea. For example, they would be destroyed if a like earthquake like the one in 1839 (which destroyed Fort-de-France) occurred (Courteau, 2007). The increasing exposure of the Martinique population to tsunami hazards, combined with a functional and economic vulnerability, including tourism pressure, makes Martinique highly exposed to tsunami risks. The occurrence of an event comparable to the one of 1755 would, nowadays, have a much more important impact on the life in the island.

This study represents the initial stage for the production of a vulnerability map concerning the tsunami hazard, using far-field sources. Further investigation of tsunami hazards in the area should consider the impact of potential local sources.

Another aspect that should be further investigated concerns the tsunami deposits. For example, a special focus on the region of Le Lorrain is presented in Fig. 4; it allows us to indicate that the wave amplification could have been sufficient here to inundate the lowlands of the river of Le Lorrain. The estuary of this river presents a kind of lagoon system, with lowlands potentially floodplain protected partially by a rocky dune; this could have stopped some of the water from the tsunami in 1755. Thus, it is a potential site to look for tsunami deposits. A second site qualified for tsunami deposits is located north of Le Lorrain and corresponds to the alluvial fan of the Capot River (Pointe des Raisiniers), presenting a lagoon profile too. Further study should model the tsunami inundation capabilities in this area, depending mainly on the dune height.

\section{Acknowledgments}

The authors would like to thank the SHOM (France) for providing the high resolution bathymetric dataset for Guadeloupe; Paul Louis Blanc (IRSN) for sending some original reports from Martinique and for discussions; João Catalão (University of Lisbon) for bathymetry digitizing and preparation of the bathymetric grid; Ronan Créach (SHOM) for his expertise on oceanic tides; Suzanne Débardat (Paris Observatory) for the understanding of historical time zones; Alain Rabaute (GeoSubSight company) for technical advices. They would like to thank Uri ten Brink (USGS) and an anonymous referee for their constructive comments for the improvement of the manuscript. This study has been funded by the project MAREMOTI from the French ANR (Agence Nationale de la Recherche), under the contract ANR08-RISKNAT-05-01c.

\section{REFERENCES}

AвE, K. (1979), Size of great earthquakes of 1873-1974 inferred from tsunami data. J. Geophys. Res. 84, 1561-1568.

AfFleck, B. (1755), An account of the agitation of the sea at Antigua, Nov. 1, 1755. By Capt. Affleck of the Advice Man of War. Communicated by Charles Gray, E/q; F.R.S in a Letter to William Watson, F.R.S.

Alasset, P.-J., Hébert, H., Maouche, S., Calbini, V., Meghraoui, M. (2006), The tsunami induced by the 2003 Zemmouri earthquake $\left(M_{\mathrm{w}}=6.9\right.$, Algeria): modelling and results. Geophys. J. Int. 166, 213-226.

Anonymous (1755), Lettre de Martinique du 15 décembre 1755, lue par Duhamel le 24 mars 1756. P.V. Séances Acad. Sci. Paris, 75, p. 145.

Anonymous (1756), Journal Historique sur les Matières du tems, juin 1756. Suite des Tremblements de Terre. pp. 462-464.

Baba, T., Mleczko, R., Burbidge, D., Cummins, P.R., Thio, H.K. (2009), The Effect of the Great Barrier Reef on the Propagation of the 2007 Solomon Islands Tsunami Recorded in Northeastern Australia. Pure Appl. Geophys. 165, 2003-2018.

BALLET, J. (1896), La Guadeloupe. Renseignements sur l'histoire, la flore, la faune, la géologie, la minéralogie, l'agriculture, le commerce, l'industrie, la législation, l'administration. Tome $\mathrm{II}^{\mathrm{e}}-$ 1715-1774. Basse-Terre, Imprimerie du Gouvernement. 
Baptista, M.A. (1998), Génese propagação e impacte de tsunamis nas costas portuguesas. PHD Thesis, University of Lisbon, Portugal (in Portuguese).

Baptista, M.A., Miranda, J.M. (2009a), Revision of the Portuguese catalog of tsunamis, Nat. Hazards Earth Syst. Sci. 9, 25-42. http://www.nat-hazards-earth-syst-sci.net/9/25/2009/nhess-9-252009.html

Baptista, M.A., Miranda, J.M. (2009b), Evaluation of the 1755 Earthquake Source Using Tsunami Modeling, in Geotechnical, Geological and Earthquake Engineering, Book Series, Vol. 7, 425-423: The 1755 Lisbon Earthquake Revisited. Springer, Netherlands. ISBN:978-1-4020-8608-3.

Baptista, M.A., Heitor, S., Miranda, J.M., Miranda, P., and Mendes-Victor, L. (1998a), The 1755 Lisbon tsunami; evaluation of the tsunami parameters, J. Geodyn. 25, 143-157.

Baptista, M.A., Miranda, P.M.A., Miranda, J.M., Mendes-Victor, L. (1998b), Constrains on the source of the 1755 Lisbon tsunami inferred from numerical modelling of historical data on the source of the 1755 Lisbon tsunami. J. Geodyn. 25(1-2), 159-174.

Baptista, M.A., Miranda, J.M., Chiericci, F., Zitellini, N. (2003), New Study of the 1755 Earthquake Source Based on Multichannel Seismic Survey Data and Tsunami Modeling, Nat. Hazards and Earth Syst. Sci. 3, 333-340.

Barkan, R., Brink, T. U., Lin, J. (2009), Far field tsunami simulations of the 1755 Lisbon earthquake: implications for tsunami hazard to the U.S. East Coast and the Caribbean. Mar. Geol. 264, 109-122.

Battistini, R. (1978), Les récifs coralliens de la Martinique. Comparaison avec ceux au sud-ouest de l'Océan Indien. Cah. O.R.S.T.O.M., sér. Océanogr. Vol. XVI (2), 157-177.

BELL, A. (1759), Map of Martinico for the latest and best authorities. Map of Guadalupe on a smaller scale. Scots Magazine. Available at http://evo.bio.psu.edu/caribmap/lesser/bodington.htm

Bouchon, C., Portillo, P., Bouchon-Navaro, Y., Louis, M., Hoetjes, P., De Meyer, K., Macrae, D., Armstrong, H., Datadin, V., Harding, S., Mallela, J., Parkinson, R., Van Bochove, J.-W., Wynne, S., Lirman, D., Herlan, J., Baker, A., Collado, L., Nimrod, S., Mitchell, J., Morrall, C., IsaAC, C. (2008), Status of Coral Reefs of the Lesser Antilles: The French West Indies, The Netherlands Antilles, Anguilla, Antigua, Grenada, Trinidad and Tobago. In: Wilkinson, $\mathrm{C}$ et al. (eds) Status of coral reefs of the world. Vol. 3, 265-280. Australian Institute of Marine Sciences, Australia.

BRUNeT, P. (attribué à -) (1850), “Journal d'un vieil habitant de Sainte-Marie (1745-1765)” ou "Ephémérides d'un vieil habitant de Sainte-Marie”). Annexe in Rufz de Lavison, Etienne (Dr), 1850. Etudes historiques et Statistiques sur la Population de la Martinique. St. Pierre. p. 394.

Chatenoux, B., Peduzzi, P. (2005), Analysis on the role of bathymetry and other environmental parameters in the impacts from the 2004 Indian Ocean Tsunami. A Scientific Report for the UNEP Asian Tsunami Disaster Task Force. UNEP/GRIDEurope. http://www.grid.unep.ch/product/publication/download/ environment_impacts_tsunami.pdf.

Chatenoux, B., Peduzzi, P. (2007), Impacts from the 2004 Indian Ocean Tsunami: analyzing the potential protecting role of environmental features. Nat. Hazards. 40, 289-304. doi:10.1007/ s11069-006-0015-9.

Cochard, R., Ranamukhaarachchi, S.L., Shivakoti, G.P., Shipin, O.V., Edwards, P.J., SeEland, K.T., (2008), The 2004 tsunami in Aceh and Southern Thailand: A review on coastal ecosystems, wave hazards and vulnerability. Perspectives in Plant Ecology, Evolution and Systematics. 10, 3-40.

Comité Martiniquais du Tourisme (2008), Bilan Grand Public. 9 p.

Courteau, R. (2007), Rapport sur l'évaluation et la prévention du risque du tsunami sur les côtes françaises en métropole et outremer. Office parlementaire d'évaluation des choix scientifiques et technologiques, $168 \mathrm{p}$.

DANEY, S. (1846), Histoire de la Martinique depuis la colonisation jusqu'en 1815; Par M. Sidney Daney, Membre du conseil colonial de la Martinique, Tome III. Fort-Royal, E. Ruelle, Imprimeur du Gouvernement. pp. 237-238.

Dao, M.H., TKalich, P., (2007), Tsunami propagation modelling-a sensitivity study. Nat. Hazards Earth Syst. Sci. 7, 741-754.

De Lange, W.P., Prasetya, G.S., Healy, T.R. (2001), Modelling of tsunamis generated by pyroclastic flows (ignimbrites). Natural Hazards, 24(3), 251-266. doi:10.1023/A:1012056920155.

Deplus, C., Le Friant, A., Boudon, G., Komorowski, J.-C., Villemant, B., Harford, C., SÉGoufin, J., CheminÉe, J.-L. (2001), Submarine evidence for large-scale debris avalanches in the Lesser Antilles Arc. Earth Planet. Sci. Lett. 192, 145-157.

Dotsenko, S.F. (1998), Numerical modelling of the propagation of tsunami waves in the Crimean Peninsula shelf zone. Phys. Oceanogr. 9(5), 323-331.

Duong, N.A., Kimata, F., Meilano, I. (2008), Assessment of Bathymetry Effects on Tsunami Propagation in Viet Nam. Adv. Nat. Sci. 9(6).

Feuillet, N., Manighetti, I., Tapponnier, P., Jacques, E. (2002), Arc parallel extension and localization of volcanic complexes in Guadeloupe, Lesser Antilles. J. Geophys. Res. 107(B12), 2331. doi:10.1029/2001JB000308.

Gutscher, M.A., Malod, J., Rehault, J.P., Contrucci, I., KlinGelhoefer, F., Mendes-Victor, L.A., Spakman, W. (2002), Evidence for active subduction beneath Gibraltar. Geology 30, 1071-1074.

Gutscher, M.-A., Baptista, M.A., Miranda, J.M. (2006), The Gibraltar Arc seismogenic zone (part 2): Constraints on a shallow east dipping fault plane source for the 1755 Lisbon earthquake provided by tsunami modeling and seismic intensity. Tectonophysics 426, 153-166.

Hébert, H., Schindelé, F., Heinrich, P. (2001), Tsunami risk assessment in the Marquesas Islands (French Polynesia) through numerical modeling of generic far-field events. Nat. Hazards Earth Syst. Sci. 1, 233-242.

Hébert, H., Reymond, D., Krien, Y., Vergoz, J., Schindelé, F., Roger J., Loevenbruck, A. (2009), The 15 August 2007 Peru earthquake and tsunami: influence of the source characteristics on the tsunami heights. Pure Appl. Geophys. 166, 1-22.

INSEE (2009), Population et logements par commune depuis le recensement de 1962 (1961 pour les Dom). Available on http://www.insee.fr/fr/themes/detail.asp?reg_id=99\&ref_id=poplogcom.

Institut GÉographique National (2006a), Fort-de-France, Montagne Pelée, PNR de la Martinique. Carte de Randonnée, 4501 MT, édition 2, 1: 25000.

Institut GÉOGRAPHIQUe National (2006b), Le Lamentin, presqu' lle de la Caravelle, PNR de la Martinique. Carte de Randonnée, 4502 MT, édition 2, 1: 25000.

Institut GÉOGRAPHique National (2006c), Le Marin, presqu'ile des trois tlets, PNR de la Martinique. Carte de Randonnée, 4503 MT, édition 2, 1: 25000. 
IOC, IHO and BODC (2003), Centenary Edition of the GEBCO Digital Atlas, published on CD-ROM on behalf of the Intergovernmental Oceanographic Commission and the International Hydrographic Organization as part of the General Bathymetric Chart of the Oceans. British Oceanographic Data Centre, Liverpool, UK.

JoHnston, A. (1996), Seismic moment assessment of earthquakes in stable continental regions. III. New Madrid, 1811-1812, Charleston 1886 and Lisbon 1755. Geophys. J. Int. 126, 314-344.

Kaabouben, F., Baptista, M.A., Iben Brahim, A., El Mouraouah, A., Тото, А. (2009), On the moroccan tsunami catalogue, Nat. Hazards Earth Syst. Sci. 9, 1227-1236.

Kowalik, Z., Murty, T.S. (1993), Numerical simulation of twodimensional tsunami run-up. Marine Geodesy. 16, 87-100.

Lander, J.F., Whiteside, L.S., Lockridge, P.A. (2002), A brief history of tsunami in the Caribbean Sea. Sci Tsunami Hazards 20, 57-94.

Le Friant, A., Boudon, G., Arnulf, A., Robertson, R.E.A. (2009), Debris avalanche deposits offshore St. Vincent (West Indies): Impact of flank-collapse events on the morphological evolution of the island. J. V. Geotherm. Res. 179(1-2), 1-10.

Le Rouge, G.-L. (1753), La Martinique une des Antilles Françoises de l'Amérique. Available at http://evo.bio.psu.edu/caribmap/ lesser/bodington.htm.

Legrand H., Rousseau Y., Pérès C., and Maréchal J.-P. (2008), Suivi écologique des récifs coralliens des stations IFRECOR en Martinique de 2001 à 2006. Revue d'Ecologie. 63(1-2), 67-84.

LetTÉE (MR) (1755), Lettre de Martinique du 5 novembre 1755, lue par Réaumur le 28 janvier 1756. P.V. Séances Acad. Sci. Paris, 75 , pp. 48-49.

LeVret, A. (1991), The effects of the November 1, 1755 "Lisbon" earthquake in Morocco. Tectonophysics 193, 83-94.

Lopez-Venegas, A.M., ten Brink, U.S., Geist, E.L. (2008), Submarine landslide as the source for the October 11, 1918 Mona Passage tsunami: observations and modeling. Marine Geol. 254(1-2), 35-46.

Machado, F. (1966), Contribuiçao para o estudo do terramoto de 1 de Novembro de 1755, Rev. Fac. Ciencias de Lisboa, $2^{\text {a }}$ Serie-C, 14(1), 19-31.

Martínez Solares, J. M., López Arroyo, A., Mezcua, J. (1979), Isoseismal map of the 1755 Lisbon earthquake obtained from Spanish data. Tectonophysics 53, 301-313.

Monserrat, S., Vilibic, I. and Rabinovich, A.B. (2006), Meteotsunamis: atmospherically induced destructive ocean waves in the tsunami frequency band. Nat. Hazards Earth Syst. Sci. 6, 1035-1051.

O'Loughlin, K.F., LANDER, J.F. (2003), Caribbean tsunamis: a 500-year history from 1498-1998. Advances in Natural and Technological Hazards Research, Kluwer Academic Pulishers, Boston, 263 pp.

Окара, Y. (1985), Surface deformation due to shear and tensile faults in a half-space. Bull. Seismol. Soc. Am. 75, 1135-1154.

Pelinovsky, E., Zahibo, N., Dunkley, P., Edmonds, M., Herd, R., Talipova, T., Kozelkov, A., Nikolkina, I. (2004), Tsunami generated by the volcano eruption on July 12-13, 2003 at Montserrat, Lesser Antilles. Sci. Tsunami Hazards, 22(1), 44-57.

Roger, J., HÉBert, H. (2008), The 1856 Djijelli (Algeria) earthquake: implications for tsunami hazard in Balearic Islands. Nat. Hazards Earth Syst. Sci. 8, 721-731.
Roger, J., Allgeyer, S., Hébert, H., Baptista, M.A., Loevenbruck, A., Schindelé, F. (2010), The 1755 Lisbon tsunami in Guadeloupe Archipelago: contribution of numerical modelling. Open Oceanogr. J. 4, 58-70.

Romero, M.L.C. (1992), El riesgo de Tsunamis en España. Analisis y valoracion geográfica. $209 \mathrm{pp}$, Insituto Geografico Nacional, Madrid. ISBN:84-7819-041-4, in Spanish

Sahal, A., Roger, J., Allgeyer, S., Lemaire, B., Hébert, H., Schindelé, F., Lavigne, F. (2009), The tsunami triggered by the 21 May 2003 Boumerdes-Zemmouri (Algeria) earthquake: field investigations on the French Mediterranean coast and tsunami modeling. Nat. Hazards Earth Syst. Sci. 9, 1823-1834.

SATAKE, K. (1988), Effects of bathymetry on tsunami propagation: application of ray tracing to tsunamis. Pure Appl. Geophys. 126(1), 27-36.

SChleupner, C. (2007), Spatial assessment of sea level rise on Martinique's coastal zone and analysis of planning frameworks for adaptation. J. Coast. Conserv. 11, 91-103.

Sladen, A., Hébert, H., Schindelé, F., Reymond, D. (2007), Evaluation of far-field tsunami hazard in French Polynesia based on historical data and numerical simulations. Nat. Hazards Earth Syst. Sci. 7, 195-206.

SMith, M.S., Shepherd, J.B. (1996), Tsunami waves generated by volcanic landslides: an assessment of the hazard associated with Kick'em Jenny. Geological Society, London, Special Publications, $110,115-123$.

Solares, J.M.M., Arroyo, A.L. (2004), The great historical 1755 earthquake. Effects and damage in Spain. J. Seismol. 8, 275-294.

Sousa, F.L.P. (1919), O Terremoto do $1^{\circ}$ de Novembro de $1755 \mathrm{em}$ Portugal. In: Um estudo demográfico Vol. I, Serviços Geológicos de Portugal e II.

Stein, S., J.F. Engeln, D.A. Wiens, K. Fujita, R.C. (1982), Speed, Subduction seismicity and tectonics in the Lesser Antilles arc. J. Geophys. Res. 87, B10, 8642-8644.

Titov, V., Rabinovich, A.B., Mofjeld, H.O., Thomson, R.E., GonZalez, F.I. (2005), The global reach of the 26 December 2004 Sumatra Tsunami. Science. 309, 2045. doi:10.1126/science. 1114576

Urban, S. (1755), Supplement to the Gentleman's Magazine for the year 1755, printed by: Henry, D. and Cave, R., St. John' Gate, London, 587-591.

Vilanova, S.P., Nunes, C.F., Fonseca, J.F.B.D. (2003), Lisbon 1755: a case of triggered onshore rupture? Bull. Seismol. Soc. Am. 93(5), 2056-2068.

Waythomas, C.F., WatTs, P. (2003), Numerical simulation of tsunami generation by pyroclastic flow at Aniakchak Volcano, Alaska. Geophysical Res. Lett. 30(14), 51-54.

Yanagasiwa, H., Koshimura, S., Goto, K., Miyagi, T., Imamura, F., Ruangrassamee, A., TAnavud, C. (2009), The reduction effects of mangrove forest on a tsunami based on field surveys at Pakarang Cape, Thailand and numerical analysis. Estuar. Coastal Shelf Sci. 81, 27-37.

Yelles-Chaouche, A.K., Roger, J., Déverchère, J., Bracene, R., Domzig, A., Hebert, H., Kherroubi, A. (2009), The Tsunami of Djidjelli (eastern Algeria) of August 21-22nd, 1856: Seismotectonic context, Modelling and implications for the Algerian coast. Pure Appl. Geophys. Topical Volume. doi:10.1007/s00024008-0433-6.

Zahibo, N., Pelinovsky, E., Yalçiner, A., Kurkin, A., Koselkov, A., Zaitsev, A. (2003a), The 1867 Virgin Island tsunami: observations and modeling. Oceanol. Acta 26(5-6), 609-621. 
Zahibo, N., Pelinovsky, E., Yalçiner, A., Kurkin, A., Koselkov, A., Zaitsev, A. (2003b), The 1867 Virgin Island tsunami. Nat. Hazards Earth Syst. Sci. 3, 367-376.

Zahibo, N., Plinovsky, E., Okal, E., Yalçiner, A., Kharif, C., Talipova, T., Kozelkov, A. (2005), The earthquake and tsunami of November 21, 2004 at Les Saintes, Guadeloupe, Lesser Antilles. Sci. Tsunami Hazards 23(1), 25-39.

Zitellini, N., Chierici, F., SArtori, R., Torelli, L. (1999), The tectonic source of the 1755 Lisbon earthquake and tsunami. Annali di Geofisica. 42, 49-55.

(Received December 31, 2009, revised May 3, 2010, accepted June 7, 2010, Published online November 13, 2010) 